Self-Help or Public Housing? Lessons from Slum Upgrading via Participatory Budget.

First Name: Ana Paula $\quad$ Last Name: Pimentel Walker

Ana Paula Pimentel Walker

Assistant Professor of Urban and Regional Planning

University of Michigan at Ann Arbor

2000 Bonisteel Blvd

Ann Arbor, MI 48109-2069

USA

Phone: 734-764-8292

E-mail: appiment@umich.edu 


\title{
Self-Help or Public Housing? Lessons from Co-Managed Slum Upgrading via Participatory Budget.
}

\begin{abstract}
What can the Participatory Budget (PB) teach us about slum upgrading in the cities of the Global South? This article describes the process of slum upgrading via PB in Porto Alegre, Brazil. Participatory budgeting _PB is a renowned mechanism of resource allocation that transfers decision-making power over the capital expenditure portion of the municipal budget from the City Council to public assemblies. However, the impact of PB on municipal service delivery in general and housing in particular is understudied.

Ethnographic findings are based on slum upgrading process via PB in an informal settlement in the East District of Porto Alegre. Fieldwork included 16 interviews with residents who had been PB delegates, PB councilors, municipal architects, lawyers, and the social worker involved in the slum upgrading project of Vila Radiante, East District. Furthermore, analysis of district-level expenditures on public works required for slum upgrading as well as analysis of site plans informed the conclusions.

The Porto Alegre PB demonstrates that slum dwellers' involvement in all stages of the slum upgrading process, from resource allocation to service delivery, contributed to the effective distribution of housing and basic infrastructure. Slum dwellers are a heterogeneous group with diverse housing needs. Housing via PB addresses this diversity and provides an alternative to the dichotomist debate in international planning between, on one hand, slum clearance followed by public housing projects and, on the other, the promotion of assisted self-help housing through programs of land tenure and basic infrastructure provision.
\end{abstract}

Keywords: Slum upgrading; housing; participatory budgeting; co-management; empowerment; Brazil

\section{Introduction}

What can the Participatory Budget(PB) teach us about slum upgrading in the cities of the Global South? In this article I describe the process of informal settlement upgrading via PB in Porto Alegre, Brazil and argue for the importance of co-management between city officials and residents of informal settlements. ${ }^{1}$ My case study demonstrates that residents' involvement in all stages of the slum upgrading process, from resource allocation to service delivery, contributed to more tailored and effective delivery of housing and basic infrastructure.

The PB is a mechanism of resource allocation that transfers decision-making power over the capital expenditure portion of the municipal budget from the city council to public assemblies.Porto Alegre was a worldwide pioneer in envisioning and implementing this idea. The Porto Alegre innovation has been acclaimed for lessening clientelism

\footnotetext{
${ }^{1}$ I use the term informal settlement and informal housing to describe self-built housing that is located in either squatter settlements or illegal subdivisions. In Brazil, illegal subdivisions are characterized by the presence of a subdivider who does not follow important legal requirements for land parceling. Thus, illegal subdivisions vary substantially in their degree of illegality and infrastructure (Fernandes, 1997: 20). Unlike squatter settlements, the plots in an illegal subdivision are at least rudimentarily marked out, therefore the settlements tend to be better planned regarding alley and roadway demarcations. I use the terms slum and squatter settlement indistinguishably.
} 
(Abers,1998),promoting redistributive justice (e.g. Santos,2005) andincreasing government accountability (Wampler, 2007). However, the impact of the PB on municipal service delivery in general and housing in particular has been understudied. This article evaluates the impact of PB as a mechanism for the delivery of public housingand slum upgrading.

Residents of informal settlements were the social group that gained most visibility,political space, and resources from the PBprocess (Pimentel Walker, 2013). Public housing, slum upgrading, street pavement, and basic sanitation figured among the top selected priorities in Porto Alegre's budgetary assemblies. Porto Alegre districts with a higher percentage of households in squatter and illegal settlements received greater amount of per capita investment in the period of 1992-2000 than the legal neighborhoods (Marquetti, 2003). This was an outstanding turn inpolitical empowerment for people living in informal housing. Participatory Budgetrecognized slum dwellers' right to participate in local politics and receive the benefits of government support.

The PBprovides practical and flexible solutions to improve the lives of those living in informal settlements. Concretely, my findings demonstrate that the seemingly incompatible policies of slum upgrading on one hand, and slum clearance followed by public housing provision on the other hand,can be reconciled as long as budgetary allocations and site plansare prepared by the residents of informal settlements in consultation with architects and planners rather than by planners alone.Given its bottom-up design, slum upgrading via PB acknowledges and addresses the diverse housing needs of those residing in these areas. Even municipalities that do not plan to implement a citywide PB program could incorporate some of its mechanisms into their housing and planning departments. The lessons learnedfrom PB in terms of slum upgrading are worth documenting andreflecting upon.

This article is based on field work for my master's thesis (December 2004-February 2005) and for my doctoral dissertation (July 2009-March 2011). I have been visiting Porto Alegre on a yearly basis for a decade and observed how residents of informal settlements in three large city districts (one downtown and two at the outskirts of the city) have placed demands for sanitation, street pavement, storm drainage, and housing through the PB. This article analyzes the findings from aninformal settlement in the East District, which I call Vila Radiante. ${ }^{2}$ In Vila Radiante, I interviewed 16 residents who had been delegates of the PB. At the time this number included all residents who had served at this volunteer position. These interviews were audio recorded, and I transcribed and translated all interviews. The shortest individual interview lasted 40 minutes and the longest, six hours.I interviewed councilors of thePB for the East District, the two architects working on the project, the municipal attorney for the housing department, and the social worker involved in the slum upgrading project. The research design also included analysis of the trends in funded priorities by the Porto Alegre's capital investments plan from 1989 to 2010 .

\section{Slum Upgrading via Participatory Budget: an Alternative Housing Policy for InformalSettlements.}

In the international planning and development literature since the 1960 s, we encounter two opposing policies towardsinformal settlements. One recommends total eradication ofinformal housing in favor of the provision of public housing (e.g.Burgess, 1978), while another recommends the fostering of self-help housing through theprovision of basic infrastructure and

\footnotetext{
${ }^{2}$ Vila Radiante is a fictitious name and pseudonyms are used to protect the identity of the interviewed.
} 
land titling programs (e.g. Turner, 1978). Slum upgrading and self-help housing approaches prevailed the debate and dominated planning practice and policy recommendations until it became clear that these approachescould not meet housing demand. As a result, the debate shifted from an almost exclusive focus on social housing (either public housing or self-help) to city-wide approaches towards comprehensive planning, local economic development, and innovative urban governancewith the goal ofproviding more holistic solutions to the needs of informal settlement residents(Bredenoord \& Lindert,2010: 280). The city of Porto Alegre, Brazil was a pioneer in terms of urban governance launching the PB program in the 1990s. Participatory Budget sprang to other municipalities in Brazil and worldwide (Cabannes, 2004; Wampler\& Hartz-Karp, 2012). Slum upgrading played an important role in the success of the program in Porto Alegre (Pimentel Walker, 2013). However, the potential of slum upgrading via PBhas not been addressed.

The transition from planning for slum clearance along withpublic housing to planning for slum upgrading reflect in part the transition from modernist and developmentalist city planningtowards models of decentralized urban development dominated by private sector planning and public-private partnerships. International planning debates andfunding policies for housing take place in connection with national housing policies anddebates in both developed and developing countries. For instance, in Brazil until the1970s the federal government addressed the problem of squatter settlements (also knownas the - housing deficit problem) through programs of squatter settlement eradication andprovision of large, low cost public housing projects (Bonduki, 1994). Then, in the 1980sand 1990s, the focus of housing policy shifted towards assisted self-help housing and slumupgrading projects. This change in Brazilian housing policy is associated with thecirculation of funding, training, and knowledge from multilateral international institutions and the United States Agency for International Development (USAID)(Benmergui, 2009).

During the 1990s and half of 2000s Porto Alegre's municipal housing department followed the national andinternational trend from squatter settlement removal and public housing provision to landtenure security and squatter settlement upgrading. However,since the late $2000 \mathrm{~s}$ Brazilian federal governmentenactedslum upgrading projects through the Programa de Aceleração do Crescimento (PAC), the Growth Acceleration Program, which was immediately followed by the financing of low- and middle- income housing through the program Minha Casa, Minha Vida (MCMV), My House, My Life (Denaldi, 2013: 45). Slum upgrading financed by PAC failed to include community participation (Lara, 2013). Thus, as the paradigms of slum upgrading and new low-income housing projects co-exist in Brazil, it is important to further explore the lessons of on-site slum upgrading and housing via PB.

The PB is a volunteer mechanism currently adopted by 351 out of the 5570 Brazilian municipalities. Brazil's 2001 Federal City Statute made participatory master plans mandatory for municipalities with more than 20 thousand inhabitants. In addition, the City Statute proposes the use of various urban planning tools to expedite the process of land regularization (Friendly, 2013: 165; Macedo,2008: 162). However, the role of PB as a mechanism of land regularization and slum upgrading has not been recognized at the federal level.

Recent research analyzed 253 Brazilian cities with over 100,000 inhabitants that adopted PB and compared them to similar cities without PB (Touchton \& Wampler, 2014). The findings reveal that cities adopting $\mathrm{PB}$ for at least eight years spend 23 percent more of their budget on sanitation and health and have a 19 percent greater reduction in infant mortality rates than cities without PB. Having PB by itself generates improvements over those municipalities without PB. 
However, having a mayor from the Workers' Party, the political party most closely associated with PB,along withPB,produces even stronger outcomes (Touchton \& Wampler, 2014: 1444). This evidence corroborates findings from ethnographic case studies that document a decline in the quality and quantity of PB process and outcomes after the departure of leftist political parties from city government (Junge, 2012; Pimentel Walker, 2015).

In terms of municipal housing policy and provision, the Porto Alegre'sPBpragmatically addresses some of the concerns of each previous planning development approach to informal housing. The slum clearance followed by resettlement into new public housing projectsbecame unpopular with the decline of the welfare state and there is little political will to invest in such projects (Ward, 1982: 9). Indeed, in the wake of John Turner's $(1972,1978)$ then groundbreaking work rejecting public housing and advocating freedom for slum dwellers to build their own housing, much literature has focused on how governments can provide residents with the tools needed for upgrading their homes. Analysts such as Paul Strassmann (1994) refined Turner's argument by adding that the best way to help residents improve their housing is to provide basic infrastructure. However, the dangerous of self-help approaches, like the one proposed by Turner, is the assumption that all persons living in informal settlements have homogenous backgrounds, will progress in life and will be able to eventually improve their homes incrementally and without the assistance of the state.

Urban ethnographies of squatter settlements (e.g. Perlman, 1976; Fonseca, 2000) acknowledge that there are socio-economic divisions in these localities between the working poor and those who are extremely impoverished. In Porto Alegre, the former hold jobs as lowskilled nurses, janitors, child care workers, street hawkers, administrative assistants, just to name a few, while the latter have only sporadic jobs as day laborers,often struggle to feed their families, and are unable to renovate their houses, even if incrementally. The fact that some dwellings consolidate fast and significantly, some modestly, while others do not consolidate at all has been explained byhousehold differences in disposable income (Ward, 1982). Nonetheless, it has been difficult to translate these findings into planning and policy. ${ }^{3}$

The institutionaldesign of PB accounts for the distinct housing needs of slumdwellers. Families with higher socio-economic status who are able to incrementallyimprove their housesusuallydo not request a public housing unit via PB. Instead, these families place demands in the PB for drainage, street pavement and sewage. By contrast, families within the lowest socio-economic status, living insub-standard housing conditions in the same squatter settlements do request public housing units via PB.What both groups have in common is the need for pavement and basic infrastructure, which is also acquired via PB. Thus, my findings demonstrate that the Porto Alegre's PB is in fact a hybrid urban planning mechanism, which includesaspects of participatory decision-making imbued with municipal service delivery. It isthis blending of housing policy-making and service delivery that makes the PB process a viable alternative to the dichotomist debate between public housingprovision and slum upgrading.

\section{The Phasesof Slum Upgrading and Housing via Participatory Budget}

Porto Alegre PB entails three modes of public participation, combining elements of direct and representative democracy (e.g. Luchamann, 2008): 1) The Council of the PB (COP); 2) the Forum of Delegates (FROP); and, 3) the Regional and Thematic Assemblies. The once a year

\footnotetext{
${ }^{3}$ It is also a challenge to translate class differentiation in the informal labor sector into public policy (Miles Doan 1992).
} 
Regional and Thematic Assemblies constitute the only instance of direct citizen participation. Participatory Budget divided Porto Alegre into 17 socio-geographic regions (districts) and six thematic forums. The direct democracy aspect of the process starts with district residents at the 17 yearly assemblies casting their ballots to select (in order of preference) four out of seventeen available priorities, such as transportation, education, health, housing, and street pavement just to name a few. Then, delegates and councilors who represent residents at the district and thematic assembliesmeet on a weekly or bi-weekly basis to rank and monitor the implementation of elected demands. For instance, at the ranking stage delegates specify the number of housing units and the meters of pavement with a starting and ending location that will be entering in the expenditure budget.

The capital investments plan is the most concrete output of the PB process. The principle of redistributive justice guides the formulas for crafting the capital investments plan.Each year, Porto Alegre defines its four citywide priorities by adding the points of the top elected priorities in the 17 districts. Once the city's four priorities are established, the districts that voted for works and services that fell within the citywide priorities have a higher percentage of their demands written into the city's investment plan. Participatory Budget allocates resources not only according to residents' elected priorities at the yearly assemblies, but also according to two other standards: a district's lack of public services or infrastructure and the total district population. The three standards altogether are called the General Criteria or the General Factors, which contribute to establishing how resources are going to be recorded in the capital investments plan (see figure 1). The allocation formula ensures that PB includes social justice principles in the distribution of funds (Sintomer et. al., 2008: 167).

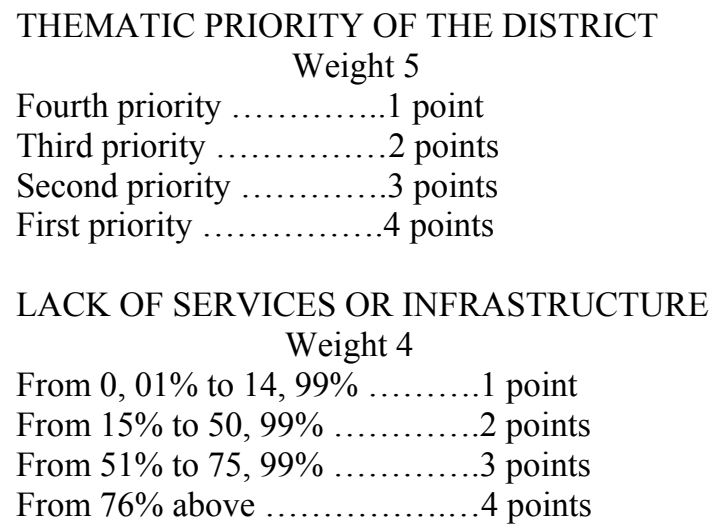

TOTAL REGIONAL POPULATION

Weight 2

Up to 25.000 inhabitants .............. 1 point

From 25.001 to 45.000 inhabitants .... 2 points

From 45.001 to 90.000 inhabitants .... 3 points

More than 90.001 inhabitants ..........4 points

The importance given to population size has been lessened since 2001, diminishing the threshold from 120.000 inhabitants to 90.001 .

Figure 1: General Criterions for Resource Distribution among Districts. Source: Participatory Budget of Porto Alegre, 2005 Bylaws.

Although low-income housing cooperatives engaged with PB, placing demands for housing in the capital investments plan (see Fruet, 2005), this article focuses on the three stages 
of slum upgrading and public housing demands via district-level elections, see figure 2. Slum upgrading demands can be channeled through the 17 once-a-year district assemblies and then ranked, implemented, and monitored by the Forum of Delegates of each district, year around. Thus, district-level delegatesco-manage all stages of the land and urban regularization (slum upgrading) process; they act as what Victoria Beard (2012) calls 'citizen planners.' Citizen planners who prior to $\mathrm{PB}$ attempted to acquire infrastructure fromthe state to aid several self-help efforts have since PB co-managed slum upgrading projects with the state. In the co-management model of slum upgrading, slum dwellers engage with all aspects of slum upgrading, from resource allocation to service delivery. In co-management, like in the co-governance model identified by Ackerman (2004), societal actors participate in some of the core functions of government.

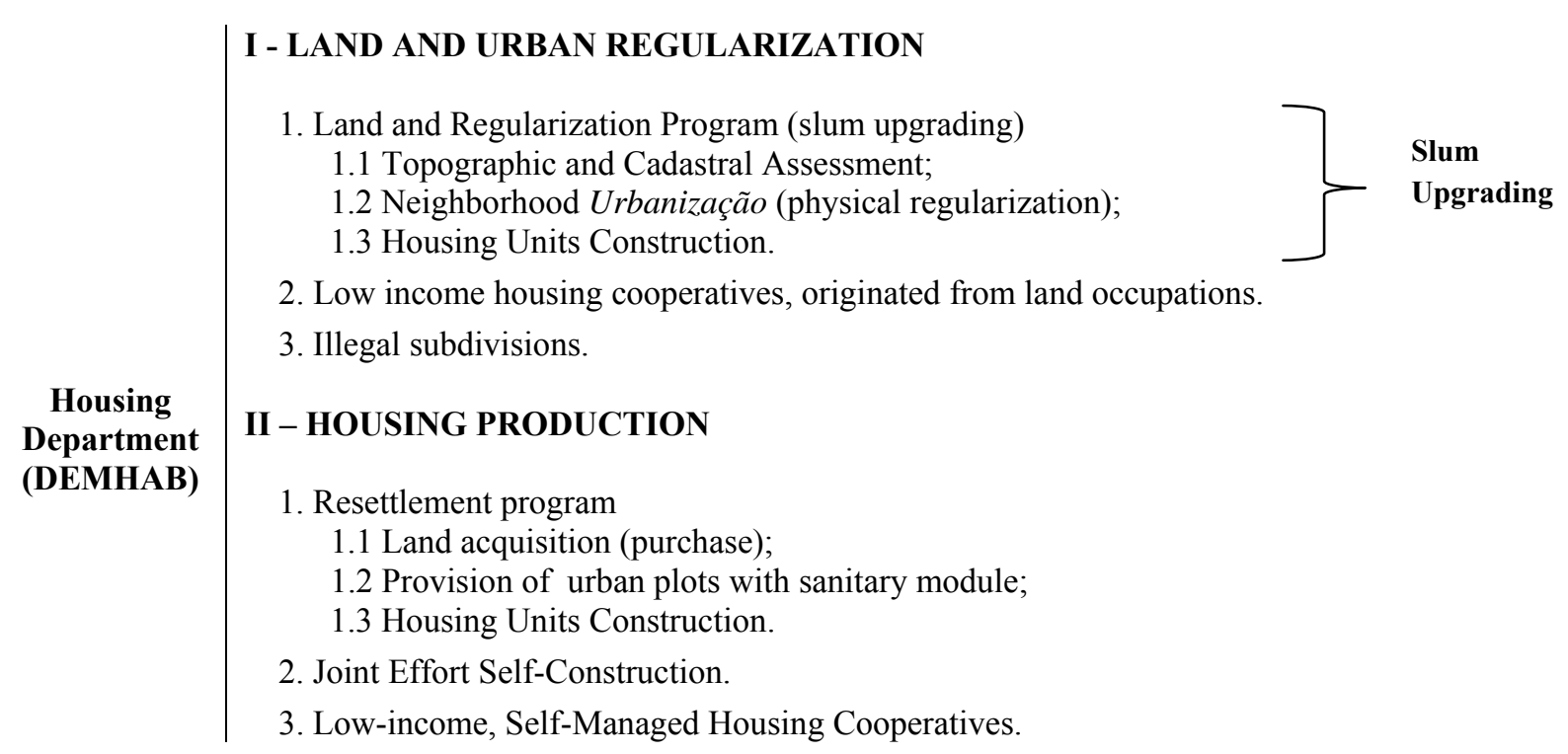

Figure 2: Sub-themes of the Housing Priority. Source: Participatory Budget of Porto Alegre, 2005 Bylaws.

As described in figure 2, land and urban regularization (slum upgrading) takes place in three budgetary phases: 1) the first stage is the PB demand for topographic and cadastral assessment; 2) the second is the request forurbanização (physical regularization or "reblocking"); and 3) the third are demands for the construction of housing units. Although slum upgrading via $\mathrm{PB}$ expedite land regularization, it does not concede full rights of use or private property. Therefore, PB follows the Brazilian model of slum upgrading, which places greater emphasis on providing adequate infrastructure and improving municipal services rather than conceding land title. The goal is to bring informal settlements into the formal city.

The topographic and cadastral assessment gathers information of the actual subdivision of house lots and produce a list of residents, which is the base for a future site plan to "reblock" the area. In virtually all cases, in order to open public streets and access, a few houses will have to be relocated. The assessment identifies the minimal standards that are deemed necessary for safety i.e. streets' minimum width for access by ambulances and small fire trucks. In PB, the process of opening public streets and accesses and rearranging house lots, called urbanização, is the second stage of the land and urban regularization process. 
The second stage, urbanização (physical regularization or "reblocking") can only be requestedin a subsequent fiscal year after the demand for topographic assessment has been recorded in the capital investments plan. The results of the topographic assessment are forwarded by the housing department (DEMHAB) to other relevant municipal secretaries and departments. It passes through the planning, drainage and sewage, and environment departments, so that these agencies can identify possible rivulets to be drained, complementary sewage, or if the settlement is located in an area of environmental preservation. Subsequently, DEMHAB receives a document identifying recommended interventions by these municipal agencies.

The minimum standards for slum upgrading are known as technical criteria and written in PB bylaws, which are revised and approved by PB councilors once a year. In theory, no housing should be allowed on slopes steeper than thirty percent, at the margins of rivulets, or at geological formations prone to mudslides. However, human settlements located in areas of environmental preservation are analyzed on a case-by-case basis with strong community input, which in practice privilege housing rights over environmental preservation. For this aspect of comanaged slum upgrading to work, it is fundamental that municipal departments allocate their experts to partner with PB delegates in order to jointly produce factual knowledge on minimum standards. The importance of institutional support for participatory budget to yield community empowerment cannot be neglected(e.g. Baiocchi and Ganuza 2014). Likewise, the relevance of joint fact-finding to produce social justice, community empowerment, and conflict mediation has been well document in urban and environmental planning (e.g. Corburn 2005; Laws and Forester 2007).

After DEMHAB receives the evaluation of the topographic assessment with the input from all the pertinent secretaries and the informal settlement wins "urbanização"via PB elections, the first step that DEMHAB takes is to contact neighborhood organizations from the informal settlements to negotiate the "reblocking." In other words, the elaboration of a subdivision map is the result of negotiations at first between PB delegates from that squatter settlement and architects from DEMHAB. Eventually architects and planners will meet with all residents at once and spend time on individual meetings with residents that will have their current lot or house affected by the relocking of streets and road accesses. After each resident signs the subdivision map plan, it goes to the Municipal Planning Secretary and to all other secretaries for analysis and approval of the urban feasibility study.

Informal settlements' associations and PB delegates are particularly important in mediating the negotiations between the Housing Department (DEMHAB) and residents. The Housing Department will only approve a plan forurbanização that is accepted and signed by all households in the squatter settlement. The subdivision plan for squatter settlement upgrading is in fact an agreement plan and the municipality employ great effort to accommodate the needs of all residents. In sum, urbanização is a type of grass-roots commissioned project for squatter settlement upgrading. The municipal administration assigns a social worker and a community liaison to collect details about people's preferences, living arrangements, and livelihoods. For instance, if residents have informal business in the squatter settlements, such as car repair shops or snack bars, the municipality assures that these economic activities will have a suitable space in the subdivision plan.

As described in the next section, the second stage presents two main challenges in crafting a collective agreement for the subdivision plan. First, the very few residents who occupy larger pieces of land than average and refuse to give part of their land to build additional houses and open or widen streets and road accesses. Second, the very low-income families who learn 
about the launching ofthe slum upgrading process via PB and move into the informal settlement, after the topographic assessment, in hopes for a new public housing unit.

The third stage of the land and urban regularization process is the construction of housing units. Residents place demands for the construction of new housing units ideally in the fiscal year following the one of the urbanização. Usually only the families living in poorly built cabins without proper construction materials and without adequate protection from weather elements request public housing units, in this case a new in situ home to replace the shack. The families that have been building their houses over the years through self-help/auto-construction fear having their homes replaced by what they consider smaller, "uglier," and less functional public housing units. In this sense, PB provides an alternative plan for addressing the housing problems in squatter settlements that is sensitive to the socio-economic diversity of the population that reside in squatter settlements. The housing solutions provided by $\mathrm{PB}$ allow for respect towards what John Turner (1972) calls the "freedom to build" aspired by dwellers engaged in self-help housing as well as for the fulfillment of the needs of those who occupy the lowest ladder of socio-economic life and do not have the resources to circumvent living in precarious shelter without the provision of public housing.

\section{Negotiated Slum Upgrading and Housing: the case of the East District in Porto Alegre}

To illustrate how architects and planners work in partnership with residents of informal settlements to effectively implement the requests for housing and slum upgrading via PB, this article focused on a particular informal settlement within the city, which I call Vila Radiante.VilaRadiante has an estimate of twelve thousand inhabitants. It belongs to the larger East district of Porto Alegre. The East district was one of the pioneers in placing demands for slum upgrading in the PB. Demands for housing and slum upgrading take many years to be fully finalized and researching the East district allowed me to identify factors that either propitiate or prevent the timely implementation of slum upgrading.

VilaRadiante is divided between four squatter settlements within a much larger area that was originally illegally subdivided. The neighborhood contains an amalgam of land claims characteristic of the formal/informal spectrum (Roy, 2005). The formerPB delegate explained:

"For the municipality, this areahas been an illegal subdivision since 1960; the landowner does not exist anymore. There are many people here without the escritura (deed), because at the City Planning Department Vila Radiante is still irregular and no infrastructure had been implemented" (Alex,legal assistant, resident of Arroio squatter settlement in Vila Radiante).

Several residents of the illegally subdivided area were able to acquire legal title over the land in court. However, for the residents of the four occupied areas in VilaRadiante, individual solutions were unfeasible. The four squatter settlements consisted of four large blocks, which were originally assigned as green space for the subdivision. These four areas appeared on the zoning map as green areas reserved for public parks and plazas. As a result of PB, slum upgrading took place and all four areas eventually became zoned for low income housing.

Both the illegal subdivision and its four squatter settlements lacked basic infrastructure prior to PB. For example, ninety percent of Vila Radiante did not have wastewater sewer connections prior to 1989 when PB started and by 2006 only ten percent lacked sewage. Before the works and services requested via PBboth areas lacked basicsanitation, drainage, and paved roads. The lack of a stormwater system was a major problem because of recurring inundations. 
Despite the mentioned precariousness, the areahad rudimentary running water (1975) andelectricity (1970-72) acquired before PB.

The physical and environmental conditions of Vila Radiante are typical of other deprived neighborhoods in the East District. The graph below demonstrates the types of physical and environmental upgrading demands that residents of the East District elected and ranked via PB. The priorities in the graph come from the municipal departments of housing; stormwater management; water and sanitary sewage; and public works (roads and public lighting). I selected these specific municipal departments and secretariats because they are responsible for the physical and environmental infrastructure involved in slum upgrading. As the data demonstrates, street pavement is requested the most often, while the construction of housing units the least.

\section{Types of Slum Upgrading Requests, East District (1989-2010)}

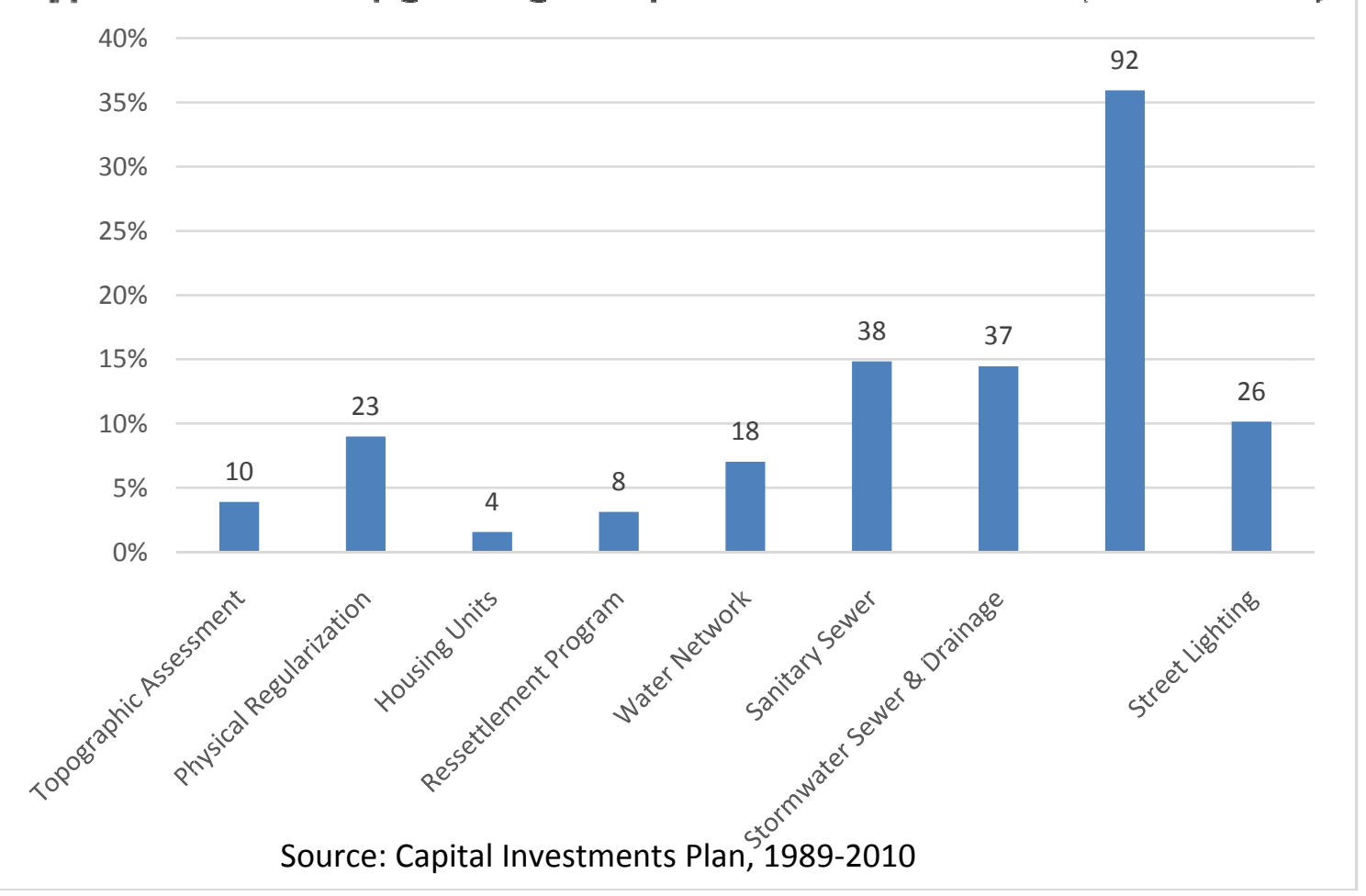

Figure 3:Types of Slum Upgrading Requests, East District (1989-2010)

The first residents of Vila Radiante to place demands at the PB lived in the illegal subdivision, which had rudimentary demarcation and roadways. Therefore, they did not need to request topographic assessment or re-blocking. Moreover, these residents had auto-constructed their houses over the years with quality construction materials and did not request public housing units. Instead, they requested street pavement, drainage, and sewage. Over the years the participation of those living in the illegal subdivision decreased while the participation of those living in the four squatter settlements increased.

Requests for street pavement can create temporary disagreement in any community. As I had mentioned, PB is a hybrid mechanism that ties up recourse allocation with municipal service delivery. Demands for street pavement appear in the capital investments budget with specific 
designations of how many meters will be paved and its precise location. Keeping the community united and moving forward to pave ninety percent of unpaved streets required multiple deliberations as one resident recalls:

"We acquired two streets per year for Vila Radiante via PB. So, we competed among ourselves to determine which streets would be paved first. It was a challenge." (James, clerical worker, resident of the School squatter settlement, Vila Radiante).

Moreover, some squatter settlement residents reported that a few residents of the illegal subdivision complained at the Forum of Delegates meetings:

"At the beginning, we saw a lot of complaints; people said, "They paved that street in front of a squatter settlement and did not pave my street." There were always some people that had this type of discrimination, there always is" (Rozilda, janitor, resident of the School squatter settlement in Vila Radiante).

Although, the two groups did not mix much socially, they have voted for many of the same demands in the PB assemblies. Some residents in the illegal subdivision may wish that those living in the squatter settlementsbe evicted; however, many worked very hard in the PB to improve the condition of their neighbors in the four squatter settlements. According to Carmen,

"There were many people at the time that even though not being as needy as we are, they sided with us, they sided for urbanização (slum upgrading), education, and everything else we asked for" (Carmen, childcare worker, Resident of the School squatter settlement in Vila Radiante).

A fewPB delegates from the squatter settlements even say that the PB process has united them. Even if the lawful tenants do not care about the living conditions of the "squatters," at least the aesthetical improvement of Vila Radiante is of common interest:

"It was shameful for them[residents of the illegal subdivision], if they had a guest or a relative that came to visit, they saw all our ugly houses, all one on the top of the other, all falling apart" (Clotilde, unemployed, resident of the Cândidasquattersettlement in Vila Radiante).

These socio-economic and spatial divides between residents of the illegal subdivision and the squatter settlements reproduce themselves inside the four squatter settlements, as some residents are better off economically than others. These socio-economic differences are reflected upon the different types of houses that they inhabit and the size of the lots that they occupy and are able to maintain. However, requests for urbanização (physical regularization) in the squatter settlements, which involves re-blocking may disturb current land possessions. As one former PB delegatereports:

"There were two people [living in the squattersettlements] that had huge areas of land. On one of the areas, they [municipal architects and planners] even put three houses [public housing units]. And on the other area the problem was the access [part of the land should become a road access]. However, we talked and talked with these two people and they finally gave up part of their land. In the end, without a problem, they gave up!" (James, clerical worker,Resident of the School squatter settlement in Vila Radiante).

The negotiations over the new plan for physical regularization in the four squatter settlements also involved the department of social services, as social workers are present to evaluate the impact of new housing arrangements on family life. For instance, childcare arrangements are taken into consideration when planning for the re-blocking of the squatter 
settlement. Relatives are not separated to avoid disrupting existing family ties that foster mutual support, such as child care. In the site plan of the formerly existing housing arrangements (figure 4), households 11,12 , and 13 are an extended family that requested to stay living next to each other in the new plan. In household 12, lives a single man who often times "watch out" for his nieces and nephews when his sister is working as a daily housekeeper.

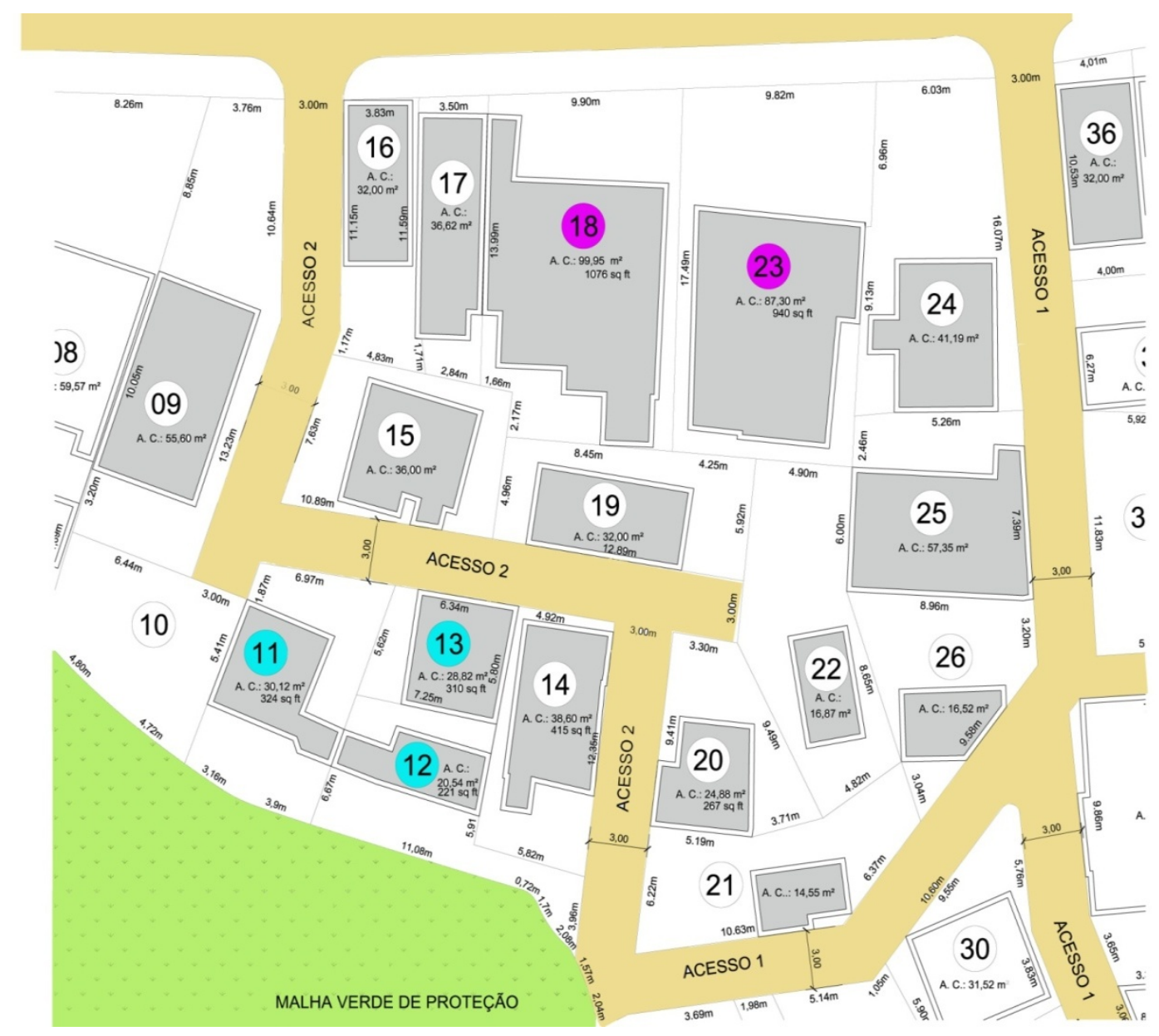

Figure 4: Partial View of Site Plan of Auto-Constructed Houses and Lots Prior to Physical Regularization, Vila Radiante, East District, Porto Alegre. Sources: Municipal Housing Department -DEMHAB. Prefeitura Municipal de Porto Alegre. Physical regularization project by architect Sonia Maria da Silva. Edited by Ana Paula Pimentel Walker and Julia Yang.

Furthermore, figure 4, demonstrates the differences in sizes of auto-constructed homes that have been preserved in the slum upgrading process (around $1000 \mathrm{sq}$. $\mathrm{ft}$.) and the small, low quality auto-constructed homes, which were replaced by public housing units (around 200 to 300 sq. ft.). Houses 18 and 23 facing the main street are auto-constructed homes that have been preserved, while houses 11,12 , and 13 becamepublic housing units allocated for the same extended family. The high quality of the auto-constructed homes can also be observed in figure 5. 


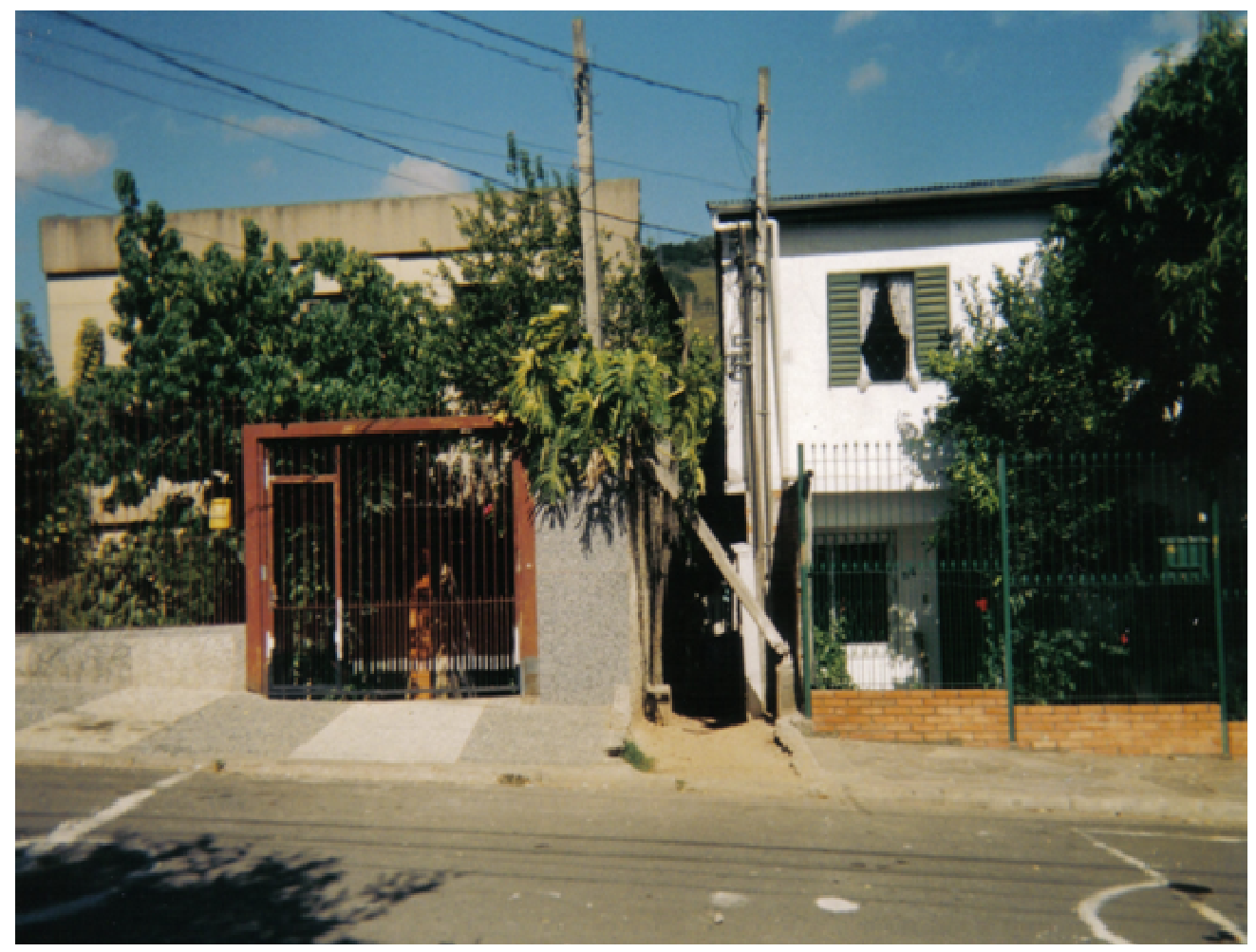

Figure 5: High Quality Auto-Constructed Homes Preserved in the Participatory Slum Upgrading Process, Vila Radiante, East District, Porto Alegre. Photo Credit: Ana Paula Pimentel Walker

Once every household has agreed upon and signed the plan for urbanização, the requests for the construction of housing units can be placed in the budget. The process of physical regularization followed by the construction of public housing units via PB occurred smoothly in three out of the four squatter settlements. Although this type of community engendered participatory slum upgrading is crafted in collaboration with municipal officials, to fulfill the needs of diverse residents, PB is not a magic bullet and cannot prevent and resolve all issues associated with informal settlements. The previous interview quote from James, a School squatter settlement resident, revealedthat the two residents occupying large plots of land in the School area agreed to have the size oftheir plots reduced to provide space for more houses and the widening and openingof access roads. Nonetheless, in the Cândida squatter settlement, the resident who occupied a large plot of landdid not agree tolose out anyportion of his land and filed a lawsuit.

As a result of the lawsuit, the municipality lost the matching funds from the federal government to financethe PB requests for new housing units placed by Cândida residents. To further complicate the process, after the lawsuitparalyzed the construction of new public housing units in the Cândida squatter settlement, a couple of the residents invited extended family members to move into the area, which generated the need for a new topographic and cadastral assessment. Until the lawsuit was settled and the new topographic assessment was completed, which took five years, only four of the twenty-eight requested public housing units had been built. In sum, only the very worst houses built on top of open ditches and with scrap materials had been immediately replaced by public housing units and many houses "in-between" the high 
quality we observe in figure 5 and the worst ones remained "as is" until legal matters had been solved and new sources of matching funds guaranteed.

\section{Co-Managed Slum Upgrading and Empowerment via Participatory Budget}

The empowerment impact of Participatory Budgets can be defined and tested in multiple ways. Political scientists concerned with civic disengagement have tested the empowerment thesis by evaluating whether or not taking part in PB increases resident participation in other institutions, such as neighborhood associations, religion organizations, and political parties (e.g. Nylen, 2002). Alternatively, scholars have argued that successful PB models require a robust civil society in order for low-income residents to gain effective decision-making power in budgetary allocations (e.g. Avrizter, 2006).

Scholars and practitioners have defined empowerment via PB in terms of social learning, highlighting that the forum of delegates and PB assemblies work as a school of citizenship and democracy in which residents learn and appropriate the language of rights and the workings of the bureaucracy and urban policies (e.g. Wampler 2007.b.,: 38; Talpin, 2011). Conversely, residents gain power when governments and bureaucracies learn from disfranchised communities (e.g. Wampler, 2007.b.). Empowerment also entails a psychological component; thus some informal settlement residents in Porto Alegre, who engaged in $\mathrm{PB}$, have experienced a change in their positional identities and increased feelings of entitlement to social rights (Pimentel Walker, 2013).

Empowered participation can be evaluated in terms of processes and outcomes (e.g. Fung, 2006; Bratt and Reardon, 2013). Empowerment evaluations based on PB processes focus on who participates and the quality of participation, while evaluations of PB outcomes focus on the redistributive justice and resident control aspects of the planning process (Baiocchi and Ganuza, 2014; Sintomer et.al., 2012). Findings in this article demonstrate that the model of comanaged slum upgrading launched by PB in Porto Alegre empowered informal settlers to take control of the housing process from budgetary allocation to the delivery of public works and services.Institutional reforms, such as the creation of the budgetary cabinet, helped guarantee joint fact-finding and co-planning between municipal departments and PB delegates and councilors.

Although co-managed slum upgrading via PB advanced social justice and resident control of the planning process, public involvement has been limited to municipal capital investments. Funds for slum upgrading programs during the 1990s and portions of the 2000s came from matching federal funds and subsidized loans from the International Bank for Reconstruction and Development (IBRD). As the federal government launched PAC and MCVC in the late 2000s to finance basic infrastructure and housing, it became clear that PB councilors and delegates in Porto Alegre had no influence on whether or not municipal governments would provide matching funds for attaining these programs. Furthermore, PAC and MCMV were designed without any meaningful input from organized housing movements or mechanisms for social control (Denaldi, 2013; Lara, 2014).

\section{Conclusion}

Researchers and practitioners have for decades acknowledged the fact that many informal settlements are heterogeneousin terms of security of tenure, the income of residents, and the 
quality of the houses (Gilbert, 2007). However, institutions usually develop urban policies that provide homogenous solutions to heterogeneous housing problems. One of the greatest advantages of housing and slum upgrading via PB is the ability of this mechanism to provide tailored solutions to complex and diverse housing situations. Despite the success of PB in providing basic infrastructure and housing for informal settlements (Marquetti, 2003; Pimentel Walker, 2013), PB is not a magic bullet and cannot prevent all problems related to slum upgrading programs. However, the co-management aspect of PB better position planners and residents to deliberate on typical conflicts related to slum upgrading, as the case study of Vila Radiante demonstrated.

The co-management aspect of housing via PB allows for joint decision-making between residents and city planners, providing the flexibility required to fulfill the diverse housing needs of heterogeneous groups of informal dwellers. Participatory Budget is famous for the direct democracy aspect of resource allocation in which residents vote for the priorities they would like to see funded. Equally important, but less celebratedaspects of the PB includesco-management in theranking and implementation of the elected priorities. Service delivery is a fundamentalcomponent of slum upgrading and many participatory programs fail at this stage.Thus, Porto Alegre's PB is in fact a hybrid urban planning mechanism, which includes aspects of participatory decision-making imbued with municipal public works and service delivery.

Housing via PB in general and informal settlement upgrading in particular provides an alternative to the institutionally provided (e.g. Burgess, 1978) versus self-help housing (e.g. Turner, 1978) debate because it allows for grass-roots, bottom-up slum upgrading that recognizes the diversity of people who are classified as squatters by local governments and international development agencies without succumbing into a model of urban development that exempts the state from providing social housing. In sum, the Housing Department only provides public housing units for those who have requested it via $\mathrm{PB}$ and respects the right to auto-construction of the working poor. Simultaneously, all households benefit from the acquired infrastructure, land tenure security, and urban regularization.

\section{Acknowledgments}

This study was supported by the National Science Foundation (award 0922573, 2009-2011) and the Foundation for Urban and Regional Studentship, 2007-2009.

\section{References}

Abers, R. N. (1998). From clientelism to cooperation: Local government, participatory policy, and civic organizing in Porto Alegre, Brazil. Politics and Society, 26(4), 511-537.

Ackerman, J. (2004). Co-governance for accountability: beyond "exit" and "voice". World Development, 32(3), 447-463.

Avritzer, L. (2006). New public spheres in Brazil: local democracy and deliberative politics. International Journal of Urban and Regional Research,30(3), 623-637.

Baiocchi, G., \& Ganuza, E. (2014). Participatory budgeting as if emancipation mattered. Politics \& Society, 42(1), 29-50. 
Beard, V.A. (2012). Citizen planners: From self-help to political transformation, In R. Weber \& R. Crane (Eds.)Oxford Handbook of Urban Planning(pp. 706-721). Oxford: OxfordUniversity Press.

Benmergui, L. (2009). The Alliance for Progress and housing policy in Rio de Janeiro and Buenos Aires in the 1960s. Urban History, 36(02), 303-326.

Bonduki, N. G. (1994). Origens da habitação social no Brasil. Análise Social, 711-732.

Bratt, R. G., \& Reardon, K. M. (2013). Beyond the Ladder: New Ideas about Resident Roles in Contemporary Community Development. Carmon, N., \& Fainstein, S. S. (Eds). Policy, planning, and people: promoting justice in urban development. (pp. 356-381). University of Pennsylvania Press.

Bredenoord, J., \& van Lindert, P. (2010). Pro-poor housing policies: Rethinking the potential of assisted self-help housing. Habitat International, 34(3), 278-287.

Burgess, R. (1978). Petty commodity housing or dweller control? A critique of John Turner's views on housing policy. World Development, 6(9), 1105-1133.

Cabannes, Y. (2004). Participatory budgeting: a significant contribution to participatory democracy. Environment and Urbanization, 16(1), 27-46.

Corburn, J. (2005). Street science: Community knowledge and environmental health justice. Cambridge: The MIT Press.

Denaldi, R. (2013). Trapped by the land? Change and continuity in the provision of social housing in Brazil. International Journal of Urban Sustainable Development, 5(1), 40-53.

Fernandes, E. (1997). Access to urban land and housing in Brazil: "Three degrees of illegality." Working papers. Lincoln Institute of Land Policy. Cambridge.

Friendly, A. (2013). The right to the city: theory and practice in Brazil.Planning Theory \& Practice, 14(2), 158-179.

Fruet, G. M. (2005). The low-income housing cooperatives in Porto Alegre, Brazil: a state/community partnership. Habitat International, 29(2), 303-324.

Fonseca, C. (2000). Família, fofoca, e honra. Etnografia de relações de gênero e violência em grupos populares. Porto Alegre: Editora da Universidade Federal do Rio Grande do Sul.

Fung, A. (2006). Varieties of participation in complex governance. Public administration review, 66(s1), 66-75. 
Gilbert, A. (2007). The return of the slum: does language matter? International Journal of Urban and Regional Research, 31(4), 697-713.

Junge, B. (2012). NGOs as shadow pseudopublics: Grassroots community leaders' perceptions of change and continuity in Porto Alegre, Brazil. American Ethnologist, 39(2), 407-424.

Lara, F. L. (2013). Favela Upgrade in Brazil: A Reverse of Participatory Processes. Journal of Urban Design, 18(4), 553-564.

Lara, F. L. (2014). Cidades na era Lula o lento abandono dos processos participativos. Revista do Instituto de Estudos Brasileiros, (58), 245-262.

Laws, D., \& Forester, J. (2007). Learning in practice: public policy mediation.Critical policy analysis, 1(4), 342-370.

Luchmann, L. H. (2008). Participação e representação nos conselhos gestores e no orçamento participativo [Participation and Representation at the Management Councils and the Participatory Budgeting], Caderno CRH 21(52), 87-97.

Macedo, J. (2008). Urban land policy and new land tenure paradigms: Legitimacy vs. legality in Brazilian cities. Land Use Policy, 25(2), 259-270.

Marquetti, A. (2003). Participação e redistribuição: o orçamento participativo em Porto Alegre. In L. Avritzer and Z. Navarro (Eds.) A inovação democrática no Brasil (pp. 129-156). São Paulo: Cortez Editora.

Miles Doan, R. (1992). Class differentiation and the informal sector in Amman, Jordan. International Journal of Middle East Studies, 24(01), 27-38.

Nylen, W. R. (2002). Testing the empowerment thesis: the participatory budget in Belo Horizonte and Betim, Brazil. Comparative Politics, 127-145.

Perlman, J. (1976). The myth of marginality: Urban politics and poverty in Rio de Janeiro. Berkeley: University of California Press.

Pimentel Walker, A. P. (2013). Embodied Identity and Political Participation: Squatters' Engagement in the Participatory Budget in Brazil. Ethos, 41(2), 199-222.

Pimentel Walker, A.P. (2015). The conflation of participatory budgeting and public-private partnerships in Porto Alegre, Brazil: The construction of a working-class mall for street hawkers. Economic Anthropology, 2(1), 165-184.

Roy, A. (2005). Urban Informality: towards an epistemology of planning. Journal of the American Planning Association, 71(2), 147-158. 
Santos, B. de S. (2005). Participatory budgeting in Porto Alegre: Towards a redistributive democracy.InB. de S. Santos (Ed.). Democratizing democracy: beyond the liberal democratic canon (pp. 307-405). London: Verso Books.

Sintomer, Y., Herzberg, C., \& Röcke, A. (2008). Participatory budgeting in Europe: potentials and challenges. International Journal of Urban and Regional Research, 32(1), 164-178.

Strassmann, P. (1994). Oversimplification in housing analysis, with reference to land markets and mobilities. Cities, 11(6), 377-383.

Talpin, J. (2011). Schools of democracy: how ordinary citizens (sometimes) become competent in participatory budgeting institutions. University of Essex: ECPR (European Consortium for Political Research) Press.

Touchton, M., \& Wampler, B. (2014). Improving social well-being through new democratic institutions. Comparative Political Studies, 47(10) 1442-1469.

Turner, J.F. (1972). Housing as a verb. In J. Turner and R. Fichter(Eds.) Freedom to build: dweller control of the housing process. (pp. 148-175). New York: McMillan Company.

Turner, J. F. (1978). Housing in three dimensions: terms of reference for the housing question redefined. World Development, 6(9), 1135-1145.

Wampler, B. (2007.a). Participatory budgeting in Brazil: contestation, cooperation, and accountability. University Park, PA: Penn State Press.

Wampler, B. (2007.b). A guide to participatory budgeting. Shah, A. (Ed.) Participatory budgeting. (21-53). Washington D.C.: World Bank Publications.

Wampler, B., \& Hartz-Karp, J. (2012). Participatory Budgeting: Diffusion and Outcomes across the World. Journal of Public Deliberation, 8(2), 1-4.

Ward, P.M. (1982). Introduction and Purpose. InP. Ward (Ed). Self-Help-housing: $a$ critique(pp.1-13). London: Mansell. 